\title{
Editorial: No Economic Justice without Gender Justice
}

\section{WENDY HARCOURT}

It seems incredible in these days of economic crisis that over 2,200 women (and some men) found the time and money to fly to Istanbul for a discussion on gender and economic justice at the AWID Forum 2012. Registrations closed a week before the event opened and the majority of the 800 organizations and individuals who answered the call for sessions and papers could not be accommodated.

Like many who attended, I spent months preparing for the event.With AWID, I organized in autumn a special meeting to plan this journal issue. I contributed to designing and participating in three of the sessions. And in the weeks in the run up to the event, I was continually promising my network of colleagues and friends that we would meet up in Istanbul to plot, to listen to each other's sessions, or find a corner somewhere to catch up. Like many others, I came to Istanbul to learn, to find and renew friendships, to be energized and to plan for the future. AWID Forums are special, highly charged, inclusive and exciting.

The secret of their success is that, in the end, they are not events but the converging of many processes. The making and attending of an AWID Forum is part of a complex networking process that brings together different generations of feminists in a space to engage, to share and create. The Development journal has been fortunate to publish now three special editions covering the outcome of the AWID Forum ${ }^{1}$ working with the ever more international and dynamic AWID team.

This journal issue is packed with insights. Cindy Clark and Lydia Alpízar Durán give a sizzling overview in their introduction of the main issues of the Forum from the epicentre of the Forum arrangements. The other articles in the Upfront section present highlights from the plenaries and in-depth sessions. Articles based on stirring speeches reflect new forms of activism and urgency in today's crisis hung world. From the defiant revolutionary poem by Marwa Sharafeldin, to the talk of a fierce new world by Gita Sen and Marilyn Waring's crisp critique of economic power; from Rhadika Balakrishnan plea for popular education, and the warnings of the misuse of culture by Yakin Ertürk, we sense a new dynamism and activism as women confront economic and social inequalities. Jayati Ghosh completes the section when she argues it is time for feminists to enter into the discussion of alternatives more forcefully in order to define how economic institutions and policies can ensure a gender-just economy and society. 
The Thematic section pushes further into how this engagement might happen with a series of articles setting out the structural reasons for the economic injustices that are impeding women's lives. Feminist economists, most of whom spoke at the AWID Forum, go to the core of economic processes in order to give a gender reading of financialization of our lives; the impact of neoliberal economic policies on women's employment; social protection policies; taxes; balancing family life; funding for women's rights, environment, well-being and livelihoods.

The Dialogue section details a vision of change by setting out feminist alternative visions to the mainstream economic development model. The three articles present: how AWID is engaged with many women's rights networks exploring alternatives; what is being constructed in Latin America by feminists and others around the Andean concept of Buen Vivir; and lastly post-development visions for Africa (anticipating Development 55.4).

The Local/Global Encounters section reports on how feminists are resisting inequitable economic processes on the ground. The articles underline women's rights defenders' economic and social struggles in the regional and national context. Whether on the streets in the US Occupy movement, or in Arab squares, or protesting at shock therapy in Greece or indigenous women defending their territories - the authors speak of passion and courage, as well as pain. The concluding photo essay captures in images the breadth of emotions and sheer diversity of women (and men) attending the AWID Forum.

None of these themes and issues will be entirely new to Development readers who will recognize that this journal issue is a continuation of many of the journal's editorial concerns. Since 2008 (and earlier), Development has been assessing and questioning the crisis in economics, exploring concepts like food sovereignty, sustaining livelihoods, climate justice, cosmovisions, Buen Vivir, civic action and the green economy.

Even given that many contributors to those issues spoke of gender equality and women's rights, true to Development's editorial line, specific issues need to be devoted to deepening an understanding of gender power relations in development. As very recent events show, women's rights and gender equality continues to be under threat. I am writing this as the results of the Egyptian election are coming in, with a win to Mohamed Morsi of the Muslim Brotherhood along with cheers of Islamists in Tahrir Square. I wonder what the young Egyptian women whom I listened to at the AWID Forum are feeling. The aftermath of the Arab Spring has not been inclusive of the women who came out on the streets 16 months ago.

I am also writing at the conclusion of the United Nations Conference on Sustainable Development Rio +20 with its messy and disappointing end. Kumi Naidoo of Greenpeace has declared it a catastrophe. Certainly the women attending were appalled. $^{2}$ The official declaration called 'The Future We Want' signed by 190 countries only 'recalls' (not recognizes) the Beijing Declaration in 1995. And any reference to support sexuality, reproductive rights and health was repressed, at the instigation of the Vatican and conservative states. Such an outcome takes women's rights back two decades.

These losses for women's rights and body politics underline that it is vital that all of us understand that gender equality and women's rights are crucial to democracy and sustainable livelihoods, to the planet's health and to all of our future. It is too much to hope that the AWID Forum and this resulting set of excellent articles alone will keep the energy and passion we require to ensure a secure and safe future.

Feminists and women's rights defenders cannot do it for themselves, whatever the Annie Lennox and Aretha Franklin song (Sisters Are Doin' It For Themselves) promises. What we need is for all people concerned about economic and social justice and development to be informed and knowledgeable on women's rights within the context of economic and the whole breadth of today's climate, food, energy and care crises. Women need to deal with economic issues from their own experience, in their own language and concerns and those experiences need to be brought to the table, as Ghosh says - feminists need to be actively engaged in the urgent task of finding alternatives. 
The journal abounds with vision and understanding of what is required - the question will be how to ensure dialogue goes beyond the AWID Forum to reach others - so that gender equity is part of future social movement strategies, new forms of development policy and democratic change. The tweets, blogs and immediate reporting via 'Open Democracy', popular radio, television and alternative media meant that the highlights, individual peoples' impressions and key messages went out immediately to tens of thousands of people. But building alliances is much harder.

So how to break out of the comfort zone of the AWID Forum? That does not mean that such Forums should not be (especially ones that are so well organized, are held in seven languages and engage so many diverse people). These spaces are vital, given that the world is decidedly not a comfortable place for most attending - the transgender people, the sex workers, domestic workers, rape survivors, those living with disabilities, indigenous women, all of whom are struggling for their rights on many levels. But we need to work hard to make connections that reach out from such events and processes in order to build open inclusive spaces, networks and pathways towards economic justice. These alliances need to be built from strategic dialogues, joint action and political engagement that should be at the basis of true democratic engagement that confronts our current injustice economic and social power structures.

\section{Notes}

1 The AWID Forum held in Bangkok: 'Women's Rights in Development', Development 49(1), (January 2006); The AWID Forum held in Cape Town: 'Power, Movements, Change', Development 52 (2), (June 2009).

2 See the Women's Major Group press release: http://www.wecf.eu/english/press/releases/2012/06/womenstatementoutcomesRio.php. 